\title{
Craig Campbell and Helen Proctor A History of Australian Schooling
}

\author{
Sydney: Allen \& Unwin, 2014. 288 pp.
}

\author{
Jean Barman \\ University of British Columbia
}

Histories of schooling can come across as just more of the same. Despite our best efforts, our attention wavers. The topic is too familiar to sustain our interest. We know all about it, or rather we think that we do. The clarity and precision of $A$ History of Australian Schooling is a powerful reminder of how much more there is to be understood and interpreted, alternatively how we might re-engage the familiar. The book is important on its own terms, but also as a mirror in which to see Canada reflected, or not.

A History of Australian Schooling acquires its authority not only from its authors' stature in the field, but also by virtue of its content. Craig Campbell and Helen Proctor enjoy broad acceptance in Australia and perhaps for that reason do not feel obliged to parade their expertise. Drawing from published sources available to readers wanting to know more, they employ direct and straightforward prose with the goal of making a complex and potentially repetitive subject broadly explicable and appealing. "We have seen our main job as the reinterpretation of the existing published record, and bringing new perspectives to old controversies" (xiii).

Consistent with Campbell and Proctor's statement of intent, the text is straightforward without being simplistic. Chapters are roughly chronological. The first three chapters span the nineteenth century from the perspectives of the earliest schools, of those in charge, and of schooling as a public good. The next four chapters track the growth and changing character of public and non-public schooling across the twentieth century. The final chapter assesses the present day and looks ahead. The points being made with words are complemented by summary tables and evocative images. Headings within chapters function as bookmarks. Chapters end with suggestions for further reading. The book is a model of accessibility.

Campbell and Proctor are, at the same time, ambitious in intent. The 'schooling' they interrogate as being integral to the making of today's Australia extends from 
kindergarten to higher education with a focus on ages six to fourteen. Those capturing their attention range from Indigenous children prior to and post contact to their non-indigenous counterparts attending both public and non-public institutions. Teachers and policy makers are also in their mandate, as is changing subject matter over time. Campbell and Proctor view schools as agents of change, if moderately so. "We do not subscribe to the view that the story of Australian schooling is one of perpetual progress, nor that it is one of descent from a golden age....Schools...have played an important part in the national story - culturally, socially, economically and even politically. There is no civic institution that has had a greater impact on social and family life" (248-49).

The caveat is, of course, that much as with Canada, it is difficult if not impossible to describe what happened everywhere in Australia at every point in time. Campbell and Proctor meet this challenge both by reminding readers of differences across the country and by employing carefully selected and well-crafted examples. As they explain, they also do so for another reason, which is the differing amounts of research across regions and time periods. These limitations help to explain why thirty-five years have passed since the last history of Australian schooling appeared.

For all that Australia and Canada share histories as onetime British colonies, systems of schooling have differed between the two countries through time. Nonindigenous attitudes and policies towards Indigenous children, definitions and functions of public vs. non-public schooling, authority accorded the central government as opposed to state/provincial counterparts, gender distinctions manifest in the classroom, the functions of assessment - for reasons that bear examination, these and other aspects of schooling are distinctive between the two countries even as there are similarities. To see ourselves from an Australian perspective is instructive. For this reason alone but also as an example of clear and accessible scholarship, A History of Australian Schooling is well worth the reading. 